\title{
Influence of the Attachment of a Gold(I) Phosphine Moiety at the Upper Rim of a Calix[4]pyrrole on the Binding of Tetraalkylammonium Chloride Salts
}

\author{
Qingqing Sun, ${ }^{[\mathrm{a}],[\mathrm{b}] \ddagger}$ Gemma Aragay, ${ }^{[\mathrm{a}] \ddagger}$ Andrea Pinto ${ }^{[\mathrm{c}],[\mathrm{d}]} \ddagger$, Elisabet Aguiló[c] ${ }^{[\mathrm{L}}$ Laura Rodríguez ${ }^{[\mathrm{c}],[\mathrm{d}] *}$ and \\ Pablo Ballester ${ }^{[a],[e] *}$
}

\begin{abstract}
We report the synthesis of an unprecedent mono-gold(I) phosphine complex based on a "two wall" aryl-ethynyl extended calix[4]pyrrole. We describe and compare the binding properties of the parent 10a,20a-bis-aryl-ethynyl calix[4]pyrrole ligand and the prepared organometallic compound as receptors for tetraalkylammonium chloride salts in dichloromethane and acetone solutions. We describe the results of ${ }^{1} \mathrm{H} N M R$, UV-vis titrations and isothermal titration calorimetry (ITC) experiments in DCM and acetone solution, aiming at thermodynamically characterize the formed complexes. The obtained results indicate a noticeable decrease in the binding affinity of the chloride for the mono-gold(I) receptor $\mathbf{1}$ compared to the parent ligand 2 . The increase in the negative value of the electrostatic surface potential at the center of the aromatic ring of the gold(I) meso-aryl-ethynyl substituent serves to explain the observed results and the presence in solution of the chloride complex of $\mathbf{1}$ as a mixture of two conformers.
\end{abstract}

\section{Introduction}

Calix[4]pyrroles are macrocyclic compounds consisting of four pyrrole units linked through their 2 and 5 positions via four tetrasubstituted $\mathrm{sp}^{3}$ hybridized meso carbon atoms. ${ }^{1,2}$ In non-polar solvents, calix[4]pyrroles exist in solution in alternate conformations. Remarkably, they are known to undergo a conformational change from alternate to cone conformation upon anion binding. However, in the solid state, examples of bound calix[4]pyrroles with neutral polar substrates demonstrated that non-cone conformations are also possible. ${ }^{3,4}$ The introduction of two aryl groups in opposed mesocarbons renders the so-called "two wall" calix[4]pyrrole as two possible constitutional isomers (Figure 1). 4,5,6,7,8 In cone conformation, the $\alpha, \alpha$-isomer displays a polar aromatic cleft ideal

[a] Institute of Chemical Research of Catalonia (ICIQ), The Barcelona Institute of Science and Technology (BIST), Av. Països Catalans, 16, 43007, Tarragona, Spain, E-mail: pballester@iciq.es

[b] Universitat Rovira i Virgili, Departament de Química Analítica i Química Orgánica, c/Marcel-lí Domingo, 1, 43007, Tarragona, Spain

[c] Departament de Química Inorgànica i Orgànica, Secció de Química Inorgànica, Universitat de Barcelona, Martí i Franquès 1-11, E08028 Barcelona, Spain. E-mail: laura.rodriguez@qi.ub.es.

[d] Institut de Nanociència i Nanotecnologia (IN2UB). Universitat de Barcelona, 08028 Barcelona, Spain

[e] ICREA, Passeig Lluís Companys, 23, 08010, Barcelona, Spain $\ddagger$ These authors contributed equally to this work.

Supporting information for this article is given via a link at the end of the document. for the binding of mono-atomic spherical anions i.e. chloride. The anion establishes four simultaneous hydrogen bonds with the pyrrole $\mathrm{NHs}$ and it is sandwiched between the opposing meso-aryl substituents, which are oriented in a parallel arrangement. Calix[4]pyrroles are known to function as heteroditopic receptors for ion-pairs, especially in non-polar organic solvents like chloroform or dichloromethane. ${ }^{9,10,11,12,13,14}$ Normally, the cation prefers to bind opposite to the anion. That is, it is partially included in the shallow and electron rich aromatic cavity defined by the four-pyrrole rings in cone conformation that is opposite the bound anion. This type of binding geometry of the ion-paired complex is referred as a receptor separated binding mode. Alternatively, the cation might be located on top of the anion resulting in an ion-paired complex with closecontact binding mode. ${ }^{10}$ In more polar organic solvents, like acetone or acetonitrile, ${ }^{15,16}$ the influence of the cation in the binding process is reduced owing to the partial dissociation of the salt ion-pair and the resulting ion-paired complexes.

The introduction of electron withdrawing and electron donating groups on the para and meta positions of the meso-aryl substituents (upper rim) of "two wall" $\alpha, \alpha$-calix[4]pyrroles modulates their binding affinity towards anions. ${ }^{5}$ Specifically, we described that anion binding with aryl-extended calix[4]pyrroles decreases with the increase in the number and electrondonating character of the aromatic substituents. This is attributed to the increase in the negative value of the Electrostatic Surface Potential (ESP) at the centroid of the aryl substituent, which produces more repulsive anion-pi interactions. $^{5}$

To the best of our knowledge, all described "two wall" $\alpha, \alpha-$ calix[4]pyrrole receptors display $C_{2 v}$ symmetry, that is their two meso-aryl substituents are identical. Likewise, the introduction of organometallic moieties in the meso-aryl substituents of these receptors remains unexplored. In particular, the introduction of

a)

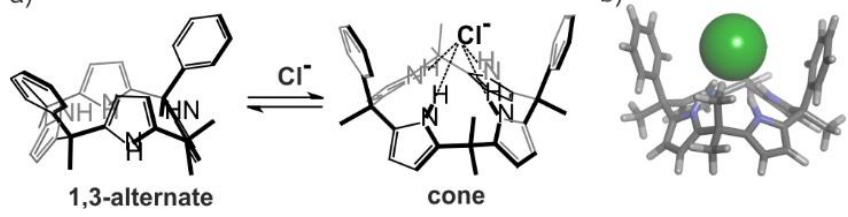

Figure 1. a) Binding equilibrium between the 1,3-alternate conformational isomer of a free "two wall" aryl extended calix[4]pyrrole and the corresponding 1:1 complex with $\mathrm{Cl}^{-}$in cone conformation. b) Energy minimized (MM3) structure of the chloride complex. The receptor is shown in stick representation and the chloride as CPK model. 
gold(I) alkynyl substituents in the meso-aryl groups would provide intrinsic luminescence properties to the receptors and their complexes. ${ }^{17}$ In this sense, calix[4]arene receptors modified with alkynyl gold derivatives showed changes in their optical properties upon cation binding. ${ }^{18,19,20}$ In addition, this type of substituents endow the supramolecular receptors with the possibility to be involved in weak aurophilic interactions (Au..Au). ${ }^{21,22}$

Herein, we describe the synthesis of the "two wall" a,a-isomer aryl-extended calix[4]pyrrole (1) bearing one gold(I) alkynyl substituent in the para-position of only one of the two meso-aryl substituents (Scheme 1). We also describe the unusual binding properties of the mono-gold(I) alkynyl derivative $\mathbf{1}$ in dichloromethane (DCM) and acetone solutions towards tetraalkylammonium chloride salts. As could be expected, calix[4]pyrrole 1 acts as an excellent heteroditopic receptor in DCM solution, displaying an impressive selectivity for the binding of methyl-tri-octyl-ammonium chloride (MTOACl) in comparison to tetra-butyl ammonium chloride (TBACl). It is important to note here that, previous reports of tetraalkylammonium ion-pairs binding by heteroditopic calix[4]pyrrole receptors demonstrated a large increase in binding affinity for salts featuring at least a methyl substituent in the organic cation. This observation was attributed to the superior fit of the methyl group in the shallow aromatic cavity opposite to the bound anion. ${ }^{12,23}$

In acetone solution, owing to the partial dissociation of the ionpairs the binding selectivity of $\mathbf{1}$ seems to level off. However, in both solvents, the resulting 1:1 fully ion-paired complex (DCM) or partially dissociated ion-paired complex (acetone) feature the bound-host in two different geometries as inferred by the observation of two sets of separate proton signals in their ${ }^{1} \mathrm{H}$ NMR spectra. Remarkably, the results of Isothermal Titration Calorimetry (ITC) experiments, performed in acetone solution for the two receptors and the two salts, fit nicely a simple $1: 1$ binding model not taking in account ion-pairing processes. The

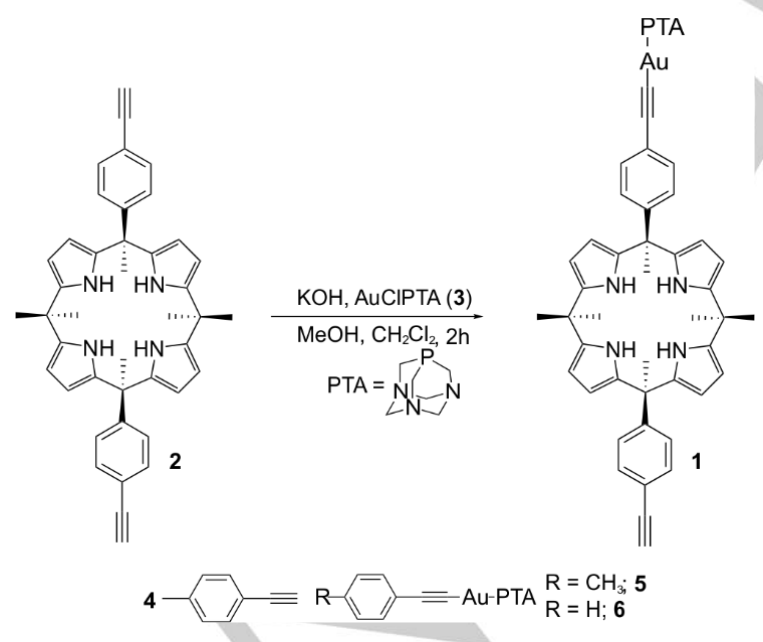

Scheme 1. Synthesis of the mono-gold(I) phosphine calix[4]pyrrole derivative 1. The molecular structure of the parent compound 2 , the gold $(I)$ salt precursor 3 and the model systems 4,5 and 6 are also shown. derived apparent binding constant values and the results of DFT calculations provide evidence for the existence of stronger repulsive chloride- $\pi$ interactions in the chloride complex of the organometallic receptor $\mathbf{1}$, which might also explain its existence in solution as a mixture of conformers.

\section{Results and Discussion}

\section{Synthesis.}

The synthesis of the gold(I) phosphine calix[4]pyrrole receptor 1 was carried out starting from 10a,20a-bis(4[ethynylphenyl])calix[4]pyrrole 2 as precursor ligand (Scheme 1). Compound $\mathbf{2}$ was prepared following a reported literature procedure. ${ }^{24,25}$

The bis-alkynyl calix[4]pyrrole $\mathbf{2}$ was deprotonated by suspending it in a $\mathrm{KOH}$ methanol solution. DCM was added to the above suspension in order to obtain a solution. Next, a DCM solution of the AuCIPTA precursor complex 3 (PTA $=1,3,5-$ triaza-7-phosphaadamantane $)^{26}$ was added dropwise. After two hours of stirring, the reaction mixture was partially concentrated and hexane was added to induce the precipitation of a pale yellow solid. The mono-gold(I) aryl-ethynyl phosphine derivative 1 was isolated in moderate yield $(60 \%)$ after precipitation of the solid from $\mathrm{CH}_{2} \mathrm{Cl}_{2}$ /hexane mixture. Compound 1 was fully characterized by a complete set of high resolution spectra (SI).

\section{Photophysical characterizations.}

The absorption and emission $\left(\lambda_{\mathrm{exc}}=300 \mathrm{~nm}\right)$ spectra of the mono-gold(I) phosphine calix[4]pyrrole $\mathbf{1}$ and the bis-aryl-ethynyl parent ligand 2 were recorded in dichloromethane solution (10 $\mu \mathrm{M})$. The most relevant absorption and emission bands are detailed in Table 1.

Excitation at $300 \mathrm{~nm}$ of a dichloromethane solution of 1 resulted in two weak emission bands with maxima at ca. $370 \mathrm{~nm}$ and 465 $\mathrm{nm}$. The bands were assigned to fluorescence and phosphorescence ${ }^{3} \mathrm{IL}$ transitions, respectively (SI). The increase of intensity of the lowest energy emission band upon oxygen removal supports the phosphorescence ${ }^{3} \mathrm{IL}$ emission assignment. On the other hand, no significant emission was detected for a solution of $\mathbf{2}$ in the same solvent neither at room temperature nor at $77 \mathrm{~K}$

Table 1 Absorption $\left(\lambda_{\max }(\mathrm{nm}),\left(\varepsilon 10^{-3}\left(\mathrm{M}^{-1} \mathrm{~cm}^{-1}\right)\right)\right.$ and emission (solution, $\lambda_{\max }$ $(\mathrm{nm})$ ) data of compounds 1 and 2 in $1 \cdot 10^{-5} \mathrm{M}$ dichloromethane solution at 298 $\mathrm{K}$ and $77 \mathrm{~K}\left(\lambda_{\mathrm{exc}}=300 \mathrm{~nm}\right)$. Fluo and Phos refer to fluorescence and phosphorescence emission bands respectively.

\begin{tabular}{|c|c|c|c|}
\hline \multirow{2}{*}{ Compound } & \multirow{2}{*}{ Absorption } & \multicolumn{2}{|c|}{ Emission } \\
\hline & & 298K & $77 \mathrm{~K}$ \\
\hline 2 & $\begin{array}{l}243 \quad(38.1), \quad 253 \mathrm{sh} \\
(27.8), 280(4.15)\end{array}$ & & \\
\hline 1 & $\begin{array}{l}243(29.11), \quad 253 s h \\
(22.06), 274(24.80), \\
288(26.52), \quad 299 \\
(21.54)\end{array}$ & $\begin{array}{l}339,370 \text { (Fluo) } \\
430,465 \text { (Phos) }\end{array}$ & 430,470 \\
\hline
\end{tabular}




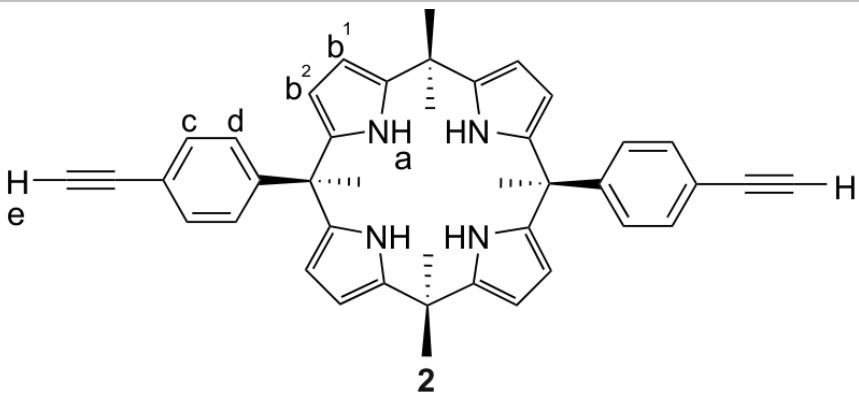

d)

\section{$\mathrm{CH}_{2} \mathrm{~N}^{+}$}

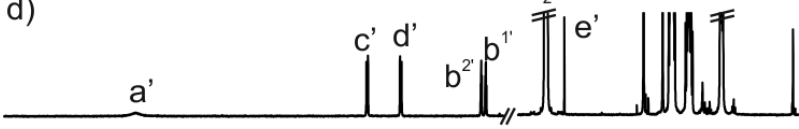

c)

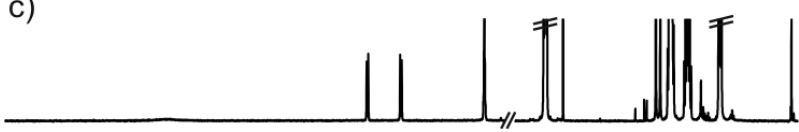

b)
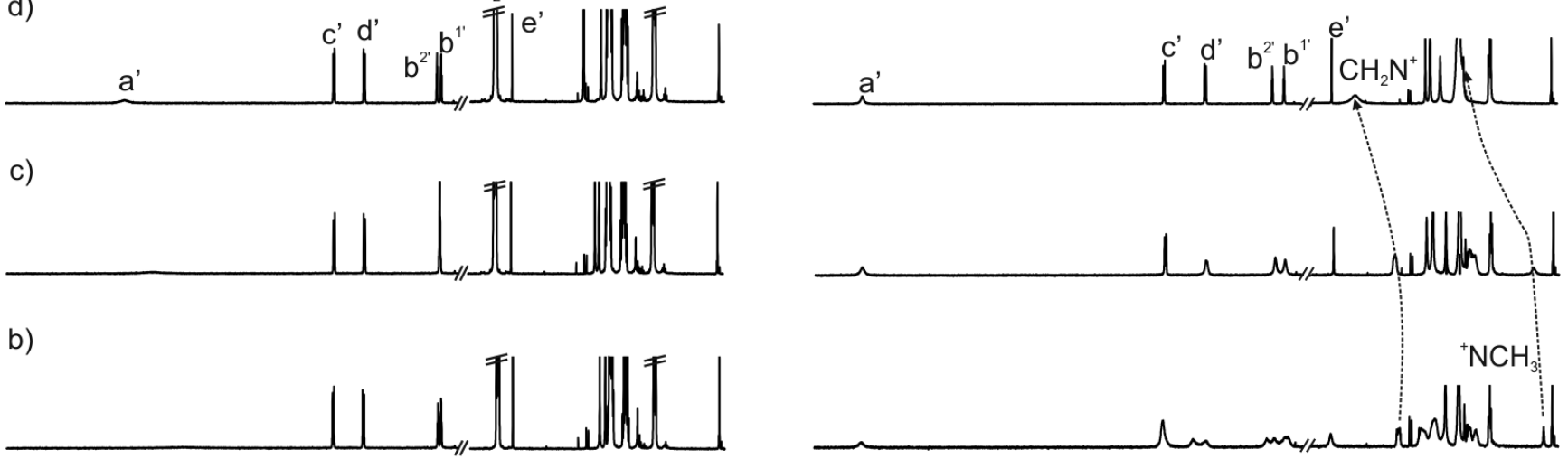

a)
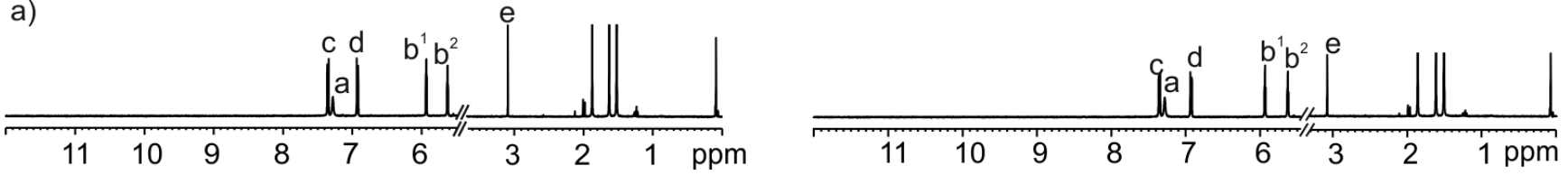

Figure 2. Left panel) ${ }^{1} \mathrm{H}$ NMR spectra acquired during the titration of $2(1 \mathrm{mM})$ with incremental amounts of TBACl in DCM solution: a) 0 equiv; b) 3.0 equiv c) 5.0 equiv and d) 10 equiv. Right panel) ${ }^{1} \mathrm{H}$ NMR spectra acquired during the titration of $2(1 \mathrm{mM})$ with incremental amounts of MTOACl in DCM solution: a) 0 equiv; b) 0.5 equiv; c) 1.0 equiv; and d) 2.0 equiv. See top panel for proton assignment. Primed signals correspond to protons in bound $\mathbf{2}$.

This result is a nice example on how heavy-atom-induced spinorbital coupling effects can induce luminescence of nonemissive chromophores, ${ }^{27,28}$ in particular, from metal-perturbed $\pi-\pi^{*}$ excited states localized on aryl-ethynyl ligands through fast population of the triplet state by intersystem crossing. ${ }^{29,30}$

\section{Binding studies of the 10a,20a-bis-aryl-ethynyl} calix[4]pyrrole 2 with tetraalkylammonium chloride salts

\section{${ }^{1} \mathrm{H}$ NMR binding studies in DCM solution}

First, we probed the interaction of the parent bis-aryl-ethynyl calix[4]pyrrole receptor 2 with TBACl and MTOACl in DCM solution using ${ }^{1} \mathrm{H}$ NMR spectroscopy. The ${ }^{1} \mathrm{H}$ NMR spectrum of 2 in DCM $(\sim 1 \mathrm{mM})$ showed sharp and well-resolved proton signals in agreement with a $C_{2 v}$ symmetry (Figure 2a). The incremental addition of TBACI (0.1-12 equiv) to the above solution induced chemical shift changes on some of the proton signals of 2 (Figure 2 left panel and $\mathrm{SI}$ ). This observation indicated that the binding process with the ion-pair experienced fast exchange dynamics on the chemical shift time-scale. The $\mathrm{NH}$ proton signal of 2 moved downfield $(\Delta \delta \sim+3.0 \mathrm{ppm})$ suggesting its involvement in hydrogen-bonding interactions with the chloride. The aromatic proton signals shifted slightly upfield $(\Delta \delta \sim-0.1 \mathrm{ppm})$ in response to the chloride- $\pi$ interactions stablished in the complex ClС2.TBA. One of the $\beta$-pyrrole protons moved upfield and the other downfield. These chemical shift changes are diagnostic that chloride binding is concomitant with a change in receptor's conformation from alternate, in the free state, to cone, in the bound receptor (See Figure 1a for details in calix[4]pyrrole conformers). Finally, the methylene protons alpha to the nitrogen atom of the TBA cation shifted downfield as its concentration was increased. This behavior supports the involvement of the TBA cation in the ion-paired complex formed in solution, ClС2·TBA, featuring a receptor separated binding mode. The TBA cation binds opposite to the anion in the electron-rich aromatic cavity defined by the pyrrole ring in cone conformation. In this location, it experiences the shielding effect of the pyrrole rings and resonates slightly upfield $(\Delta \delta=-0.12 \mathrm{ppm}$ when 0.1 equiv are added) with respect to the chemical shift value of the TBA in the TBACI ion-pair $(\delta=3.3$ $\mathrm{ppm})$. As the concentration of TBA is increased, the amount of TBA in the free ion-pair, TBACI, also increases with respect to

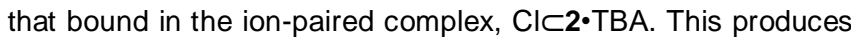
that the signal of the TBA methylene protons moves towards $\delta=$ $3.3 \mathrm{ppm}$ owing to the fast chemical exchange regime that is operative for the equilibrium between the TBA cation in the salt ion-pair, TBACl, and ion-paired complex, Clс2•TBA. The partial formation of the ClС2.TBA complex in an equimolar mixture of the binding partners at a concentrations suitable to acquire the 
${ }^{1} \mathrm{H}$ NMR spectrum $(\sim 1 \mathrm{mM})$ allowed us to estimate that the binding constants of the ClС2•TBA complex considering a 1:1 stoichiometry must be lower than $10^{4} \mathrm{M}^{-1}$. The fit of the chemical shift changes experienced by the $\beta$-pyrrole protons signals during the titration to a theoretical binding model was good and afforded a more accurate value for the binding constant as $\mathrm{K}(\mathrm{Cl} \subset 2 \cdot \mathrm{TBA})=2.7 \times 10^{2} \mathrm{M}^{-1}(\mathrm{SI})$.

The analogous ${ }^{1} \mathrm{H}$ NMR titration of receptor 2 with $\mathrm{MTOACl}$ provided significant different results (Figure 2, right panel). Thus, the addition of 0.5 equiv of $\mathrm{MTOACl}$ produced broadening of some signals of the receptor, as well as the observation of two set of separate signals of equal intensity for others. One of the two sets corresponded to the free receptor, while the new one was assigned to the protons in bound 2 . In the presence of 1 equiv of MTOACl only the set of signals corresponding to bound 2 was detected. The addition of more than 1 equiv of the ion-pair salt induced the sharpening of the signals of the receptor but it did not produce any chemical shift changes. Taken together, these observations indicate that 2 and MTOACI formed a 1:1

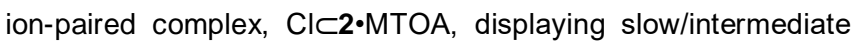
exchange dynamics on the chemical shift timescale between the free and bound receptor. We can also estimate that the binding constant value for the $1: 1$ complex $\mathrm{K}(\mathrm{Cl} \subset \mathbf{2} \cdot \mathrm{MTOA})$ is larger than $10^{4} \mathrm{M}^{-1}$, owing to its almost quantitative formation in an equimolar mixture of the binding partners. In analogy to the TBA cation, the MTOA cation must be also located in the electronrich and shallow cavity defined by the pyrrole rings of bound 2 . The methyl group, alpha to the nitrogen atom of the MTOA cation, resonates highly upfield shifted $(\delta=0.19 \mathrm{ppm})$ owing to its deeper inclusion in the aromatic cavity, where it experiences the strong shielding effect caused by the four aromatic pyrrole rings. The methylene groups alpha to the nitrogen atom of the MTOA cation are more exposed and affected to a lesser extent. We also assigned a separated receptor binding geometry to the $\mathrm{Cl} \subset 2 \cdot \mathrm{MTOA}$ complex. When more than 1 equiv of $\mathrm{MTOACl}$ is added, the signals of the methyl and methylene proton atoms alpha to the nitrogen start moving downfield. This dynamic behavior derives from fast chemical exchange process that exist between the MTOA cation in free and bound ion-pairs, MTOACl and $\mathrm{Cl} \subset 2 \cdot \mathrm{MTOA}$, respectively.

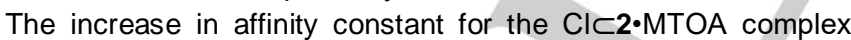
(estimated as $>10^{4} \mathrm{M}^{-1}$ ) compared to that of the Clс2.TBA counterpart $\left(\mathrm{K}(\mathrm{ClC2} \cdot \mathrm{TBA})=2.7 \times 10^{2} \mathrm{M}^{-1}\right)$ supports that receptor $\mathbf{2}$ is acting as a heteroditopic receptor in DCM solution. The superior fit of the methyl group of the MTOA cation in the aromatic cavity opposed to the bound chloride is mainly responsible of the observed selectivity.

\section{UV-vis titrations in DCM solution}

In order to determine an accurate value for the binding constant of the $\mathrm{Cl} \subset 2 \cdot \mathrm{MTOA}$ complex, we also probed the binding process using UV-vis titrations $([2]=20 \mu \mathrm{M})$. We observed a nonmonotonic behavior for the absorbance changes at most wavelengths (Figure 3). For example, at the maximum of the band centered at $242 \mathrm{~nm}$, the absorbance intensity decreased until the addition of 6.4 equiv and started to increase when more equivalents of the salt were added. This biphasic behavior suggested the co-existence in solution, at this lower

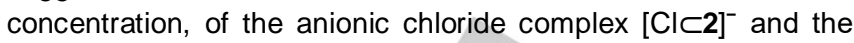
ion-paired counterpart Clс2.MTOA in significant extents. Flood and co-workers analyzed ${ }^{1} \mathrm{H}$ NMR titration data of a triazolophane receptor with $\mathrm{TBACl}$ in $\mathrm{DCM}$ solution, displaying fast chemical exchange on the chemical shift timescale, as well as the corresponding UV-vis data using an elaborated binding model. ${ }^{31}$ We applied a closely related binding model, which considers the ion-pairing of the MTOACI salt $\left(\mathrm{K}_{\mathrm{ip}}\right)$, the formation

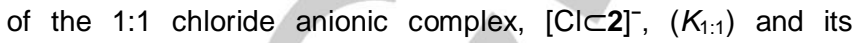
subsequent ion-pairing to yield the ternary complex $\mathrm{Cl} \subset 2 \cdot \mathrm{MTOA}$ $\left(K_{1: 1 i p}\right)$, to perform the mathematical analysis of the UV-vis titration data using the HypSpec software. ${ }^{32}$ It is worth to note that the unrestricted factor analysis in HypSpec of the UV-vis titration data already revealed three mathematically significant light absorbing species. During the fit, we fixed the value of the ion-pairing of the MTOACl salt as $K_{\mathrm{ip}}=3.0 \times 10^{4} \mathrm{M}^{-1} .^{31} \mathrm{We}$ manually optimized the values of $K[\mathrm{Cl} \subset 2]^{-}$and $K(\mathrm{Cl} \subset 2 \cdot \mathrm{MTOA})$. The returned values for the best fit, which also provided sensible UV-vis spectra for $[\mathrm{Cl} \subset 2]^{-}$and $\mathrm{Cl} \subset 2 \cdot \mathrm{MTOA}$, were $\mathrm{K}[\mathrm{Cl} \subset 2]^{-}=6.3$ $\times 10^{4} \mathrm{M}^{-1}$ and $\mathrm{K}(\mathrm{ClC2} \cdot \mathrm{MTOA})=6.3 \times 10^{8} \mathrm{M}^{-2}$. Based on Fuoss' law, ${ }^{33}$ as well as in previous results reported by Flood and coworkers, the equilibrium constant of complex ion-pairing constant $K\left([\mathrm{Cl} \subset 2]^{-}\langle\rightarrow \mathrm{Cl} \subset 2 \cdot \mathrm{MTOA})\right.$ should be smaller than the $K_{\text {ip }}$ of the MTOACl salt. Based on the values returned from the fit, we calculated $K\left([\mathrm{Cl} \subset 2]^{-}(-) \mathrm{Cl} \subset 2 \cdot \mathrm{MTOA}\right)=1.0 \times 10^{4} \mathrm{M}^{-1}$. The value is in agreement with our expectations, thus providing some indication of the quality and fit of the data analysis. If the Clс2•MTOA complex is considered to have a 1:1 stoichiometry, its apparent average binding constant can be estimated as $K($ Clс2・MTOA $)=\left(6.3 \times 10^{8} \mathrm{M}^{-2}\right)^{1 / 2}=2.5 \times 10^{4} \mathrm{M}^{-1}$. In doing so, we can determine that the $\mathrm{Cl} \subset 2 \cdot \mathrm{MTOA}$ complex is two orders of magnitude more stable than the Clс2•TBA analogue.

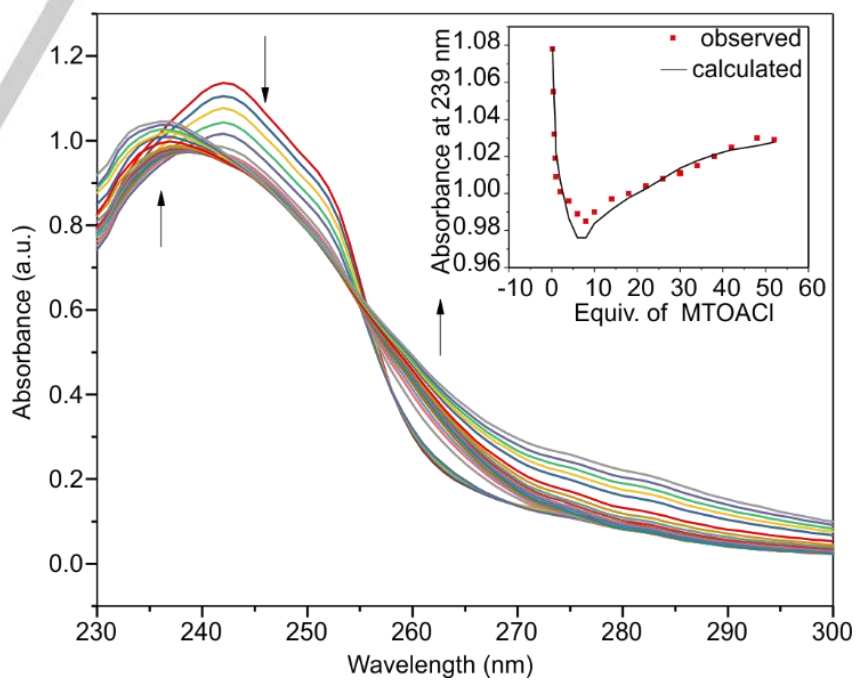

Figure 3. UV-vis spectra acquired for the titration of $2(20 \mu \mathrm{M})$ with $\mathrm{MTOACl}(0-$ 52 equiv) in DCM solution. Inset: Fit of the titration data to the extended binding model at $239 \mathrm{~nm}$. The biphasic behaviour of the titration data is nicely reproduced by the extended binding model (see text for details).

The analogous titration of 2 with incremental amounts of TBACl lead to a steady diminution of absorbance. Even after the 
addition of 32 equiv of the salt, we did not reach the saturation point. We concluded that the observed spectral changes were not suitable for further mathematical analysis of the binding process. Most likely, at this concentration ([2] $=20 \mu \mathrm{M})$ the extent at which the complexes (anionic and ion-paired) are formed in solution is low and the absorbance changes might be mainly related to the increase of the dielectric constant of the media.

Taken together, the results of the UV-vis titrations support that at $\mu \mathrm{M}$ concentrations the anionic complex $[\mathrm{Cl} \subset 2]^{-}$is present at very low concentrations and the ion-paired counterpart, independently of the cation, is the almost exclusive complex formed in solution. This finding is a direct consequence of the fact that the values of the ion-pairing constant in DCM for the salts and complexes are larger than $10^{4} \mathrm{M}^{-1}$.

\section{ITC titration in DCM solution}

The binding of MTOACl with receptor 2 in DCM was also investigated by isothermal titration calorimetry (ITC). Noteworthy, the resulting binding isotherm showed a single sigmoidal behavior that nicely fit to a simple $1: 1$ binding model (SI). The determined apparent binding constant was $K(\mathrm{Cl} \subset 2 \cdot \mathrm{MTOA})=6.0 \pm 0.5 \times 10^{4} \mathrm{M}^{-1}$, which is in the same order of magnitude to the one estimated for the formation of the complex in a single step form the UV-vis titration (vide supra). The binding of chloride to receptor $\mathbf{2}$ is enthalpically driven and highly exothermic, as might be expected for a binding process in taking place in a non-polar solvent.

\section{Binding studies of the mono-gold(I) phosphine calix[4]pyrrole derivative 1 with tetraalkylammonium chloride salts}

Having clarified the binding properties of the parent ligand 2 towards MTOACI and TBACI in DCM solution, we felt prepared to analyze those of the organometallic gold(I) derivative 1.

\section{General considerations}

The substitution of the terminal alkynyl hydrogen atom of an aryl-ethynyl substituent by a gold(I)•PTA residue should have a strong impact on the electronic properties of the phenyl group. We therefore performed DFT calculations in order to determine the modification of the electrostatic surface potential (ESP) at the center of the aromatic ring provoked by this substitution. We computed the ESPs of 1-ethynyl-4-methyl benzene $\mathbf{4}$ and [2-[4(methyl)phenyl]ethynyl](1,3,5-triaza-7-phosphaadamantane$\kappa P) A u(I) 5$ (Scheme 1), as model systems of the two different aromatic walls present in the mono-gold(I) phosphine calix[4]pyrrole derivative 1 , at the BP86 $6^{34,35}-\mathrm{D} 3^{36} /$ def2-SVP level of theory using GAUSSIAN version 09 (Figure 4). ${ }^{37}$

As shown in Figure 4, the introduction of the gold(I)•PTA as terminal residue of the ethynyl substituent doubles the ESP value at the center of the aryl ring. This result indicates that the aryl ring with the gold(I)•PTA unit becomes more electron rich and prone to be involved in a more repulsive anion- $\pi$ interaction than an analogous compound with a simple ethynyl substituent.

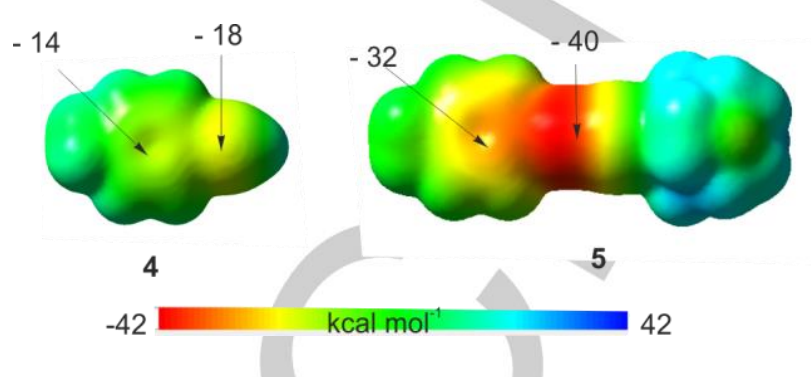

Figure 4. Calculated ESP values for the model systems 4 and 5 of the aromatic walls in 1. ESP cubes mapped at electron density value of 0.0004 a.u.

We estimated that ESP values of the order of $-12 \mathrm{kcal} / \mathrm{mol}$ at the center of the aromatic ring corresponded to a free energy value of the chloride- $\pi$ interaction close to $0 \mathrm{kcal} / \mathrm{mol}$. We also demonstrated the existence of a linear-relationship between ESP and $\Delta \Delta G$ values for chloride- $\pi$ interactions. ${ }^{5}$ By extrapolation of this linear relationship, we assign a significant repulsive interaction, $\Delta \Delta \mathrm{G} \sim 0.8 \mathrm{kcal} \mathrm{mol}^{-1}$, between the anion and the aryl of the gold $(\mathrm{I})$-ethynyl phosphine substituent $(\mathrm{ESP}=$ $-32 \mathrm{kcal} \mathrm{mol}^{-1}$ ).

\section{${ }^{1} \mathrm{H}$ NMR titrations in DCM solution.}

We first probed the interaction of mono-gold(I) phosphine calix[4]pyrrole derivative 1 with $\mathrm{MTOACl}$ and TBACl using ${ }^{1} \mathrm{H}$ NMR spectroscopy. Calix[4]pyrrole 1 has a reduced solubility in DCM solution. Its ${ }^{1} \mathrm{H}$ NMR spectrum in DCM solution showed four aromatic proton signals in agreement with a $C_{\mathrm{s}}$ symmetry. The aromatic protons for the ethynyl substituted meso-phenyl group resonate as doublets at $\delta=7.34$ and $6.92 \mathrm{ppm}$. The latter signal corresponds to the aromatic proton ortho to the mesocarbon. In turn, the aromatic protons of the meso-phenyl bearing the p-ethynyl gold(I)•PTA substituent appear slightly upfield shifted at $\delta=7.19$ and $6.81 \mathrm{ppm}$ (Figure 5a - left panel). The difference in observed chemical shifts is in agreement with the meso-phenyl having the pristine ethynyl substituent being more electron-poor, as it is also derived from the DFT calculations. The protons of the PTA ligand appear as three separate signals. Two doublets corresponding to the axial and equatorial protons of the six-membered ring containing the three nitrogen atoms and one singlet for the methylene protons connecting the nitrogen atoms to the phosphorus. The four chemically nonequivalent $\beta$-pyrrole proton $\left(\mathrm{Hb}^{1}-\mathrm{Hb}^{4}\right)$ produced only two separate signals. The addition of incremental amounts of each salt to separate DCM solutions of $\mathbf{1}$ produced changes in the registered ${ }^{1} \mathrm{H}$ NMR spectra that are identical to those described by the parent ligand $\mathbf{2}$ in the corresponding previous section. 


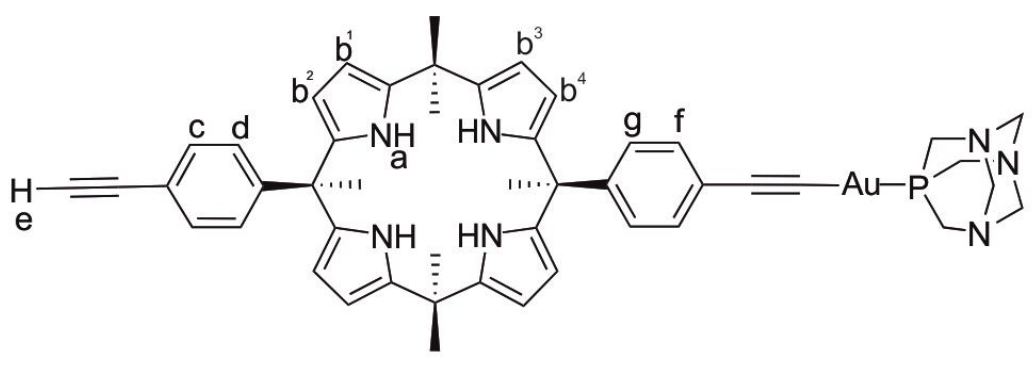

1

e)
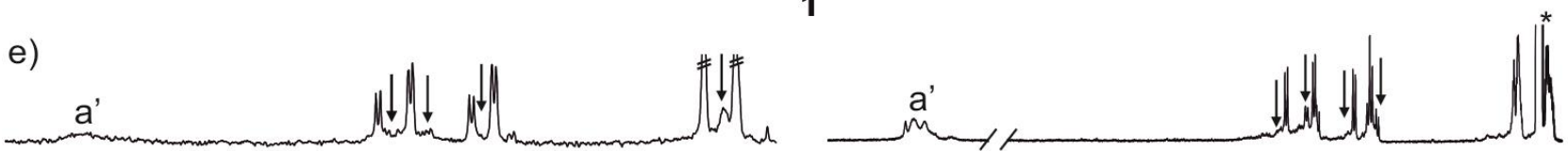

d)
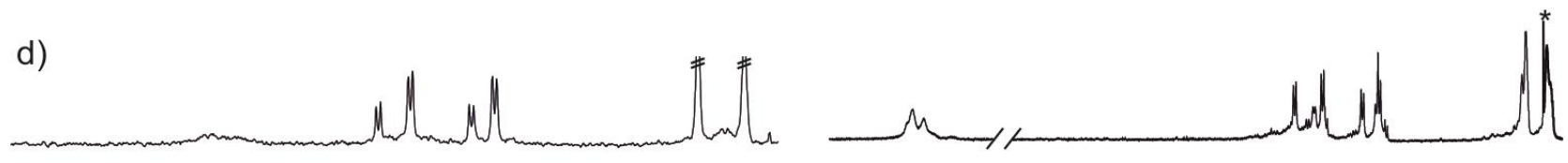

c)
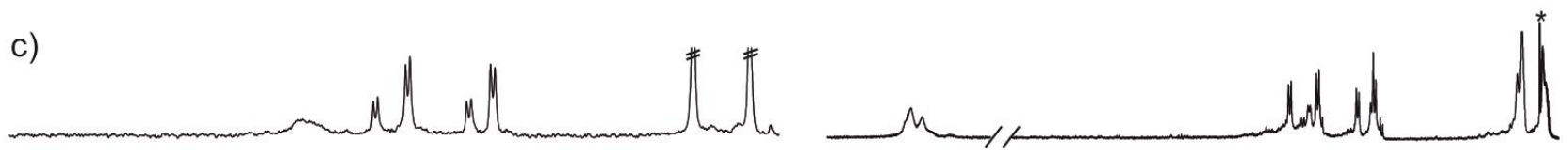

b)
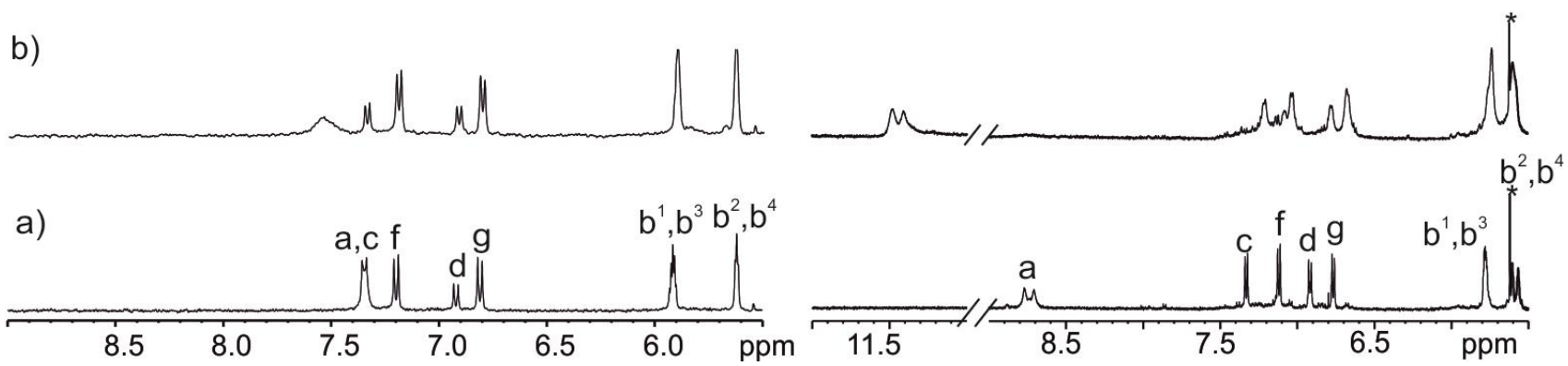

Figure 5. Left panel) Downfield region of the ${ }^{1} \mathrm{H}$ NMR spectra acquired during the titration of 1 (1 mM) with incremental amounts of TBACl in DCM solution: a) 0 equiv; b) 0.5 equiv; c) 1.0 equiv; d) 2.0 equiv and e) 3.0 equiv. Right panel) Downfield region of the ${ }^{1} \mathrm{H}$ NMR spectra acquired during the titration of 1 (1 $\mathrm{mM}$ ) with incremental amounts of TBACl in acetone- $d_{6}$ solution: a) 0 equiv; b) 0.5 equiv; c) 1.0 equiv; d) 2.0 equiv and e) 3.0 equiv. See top panel for proton assignment. Primed signals correspond to protons in bound 1. Black arrows correspond to a new set of emerging proton signals for the bound 1.

The most relevant changes are the downfield shift of the pyrrole $\mathrm{NH}$ protons of the bound receptor, indicating the involvement of these protons in hydrogen bond interactions with the bound anion. In short, the mono-gold(I) phosphine 1 also acts as a heteroditopic receptor for ion-pairs in DCM solution. ${ }^{38}$ The obtained results served to estimate that the binding constant $K(\mathrm{Cl} \subset 1 \cdot \mathrm{MTOA})$ is still larger than $10^{4} \mathrm{M}^{-1}$. On the other hand, the fit of the chemical shift changes experienced by the protons of 1 in the titration with TBACl to a $1: 1$ binding model assigns the value of $K\left(\mathrm{ClC1} \cdot \mathrm{TBA}\right.$ ) lower than $50 \mathrm{M}^{-1}$ (Figure 5- left panel and $\mathrm{SI}$ ). The reduction in the magnitude of the binding constant

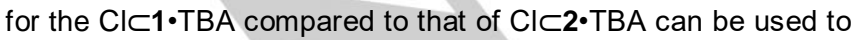
assign a value of $0.6 \mathrm{kcal} \mathrm{mol}^{-1}$ as a minimum estimate of the chloride- $\pi$ interaction that putatively operates in

the former. Gratifyingly, this value is in the same order of magnitude with our predictions.

Noteworthy, we encountered a much-unexpected observation in the ${ }^{1} \mathrm{H}$ NMR titration experiments of $\mathbf{1}$ in DCM solution. That is, the appearance of second set of signals for the bound receptor 1 (Figure $\mathbf{5}$ - left panel). These signals became visible when we added the salt over the equimolar point and remained as low intensity signals after further incremental addition. We surmised that the ion-paired chloride complex of $\mathbf{1}$ could be present in solution as a mixture of two conformers of the bound receptor.

\section{Attempts to perform UV-vis titrations of 1 in DCM solution.}

We titrated a solution of 1 in DCM $([1]=10 \mu \mathrm{M})$ with incremental amounts of $\mathrm{MTOACl}$ ( 0 - 75 equiv) maintaining the concentration of the receptor constant throughout the titration. We observed the steady decrease of the absorbance of all the bands in response to the addition of the salt. Surprisingly to us, the change of absorbance did not reach saturation or showed signs of a biphasic behaviour as observed for 2 . The UV-vis titration of 1 in DCM solution using TBACI displayed an identical behaviour (SI). 
We prepared the organometallic gold complex 2-phenyl-ethynyl(1,3,5-triaza-7- phosphaadamantane-kP)Au(I), 6 (Scheme 1), as model system of the metallated aromatic wall of 1 , in order to examine the effect caused by the incremental addition of tetraalkylammonium chloride salts on its absorption spectrum. We were surprised to discover that the absorbance of the UV-vis spectrum of 6 in DCM solution decreased as the amount of the salts increased $(\mathrm{SI})$. Based on these results, we concluded that UV-vis spectroscopy is not a suitable technique to study the binding of chloride to the mono-gold(I) alkynyl receptor 1 . The absorption spectrum of the chromophore is modified in response to a process that is not directly related to the chloride binding.

\section{Additional ${ }^{1} \mathbf{H}$ NMR titrations of $\mathbf{1}$ in acetone solution.}

In order to gain further evidence of the presence of two chloride complexes of $\mathbf{2}$ in solution, possibly a mixture of conformers, we performed additional titration experiments of $\mathbf{1}$ with the two salts in acetone solution. In acetone solution, the ion-pairing is expected to be weaker and this might facilitate the formation of the second chloride complex to a different extent. Moreover, the oxygen atom of acetone is a good hydrogen bond acceptor. The putative formation of hydrogen bonds between the solvent and dangling pyrrole $\mathrm{NHs}$ could favor the chloride bound receptor to adopt other conformations than the cone. In this respect, we observed in the solid-state that "two wall" calix[4]pyrroles adopt alternate conformation when bound to polar solvents like acetone or acetonitrile (see SI for X-ray of 2). ${ }^{4,39}$

The gold(I) metallated calix[4]pyrrole $\mathbf{1}$ also features a very reduced solubility in acetone- $d 6$. We titrated $1 \mathrm{mM}$ solutions of 1 with incremental amounts of both salts, TBACl and MTOACl, in separate NMR tubes. Contrary to the experiments carried out in DCM solution, but in agreement with our expectations, the results of the titrations with the two salts are quite similar. In short, the more polar environment provided by acetone minimizes ion-pairing and $\mathbf{1}$ behaves mainly as a monotopic anion receptor (Figure $\mathbf{5}$ - right panel and $\mathrm{SI}$ ).

In both titrations, the chloride binding saturates after the addition of 1 equiv of the salt. The addition of more than 1 equiv of the salt induces small changes in the protons of the bound receptors All in all, these results are consistent with a binding affinity of 1 for chloride in acetone- $d_{6}$ solution, $K\left[\mathrm{Cl} \subset 1 \Gamma\right.$, larger than $10^{4} \mathrm{M}^{-1}$. Unfortunately, at this point, the lack of accurate binding constant values for the $[\mathrm{Cl} \subset 1]$ and $[\mathrm{Cl} \subset 2]^{40}$ anionic complexes in acetone- $d_{6}$ does not allow us to test our theoretical predictions in favor of the energetically more favorable [Clᄃ2] complex, owing to the reduced repulsive chloride- $\pi$ interactions (see section on ITC experiments in acetone to overcome this limitation).

\section{Molecular Modelling Studies}

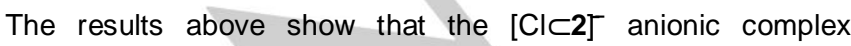
(acetone solution) and its ion-paired counterparts Clс2·TBA/MTOA (DCM solutions) are present in solution as single conformers featuring a unique binding geometry in the latter case. In striking contrast, the complexes of the monogold(I) phosphine calix[4]pyrrole $\mathbf{1}$ exist in solution as mixture of two conformers and possibly with different binding geometries.
We ascribed this difference to the existence of stronger repulsive chloride- $\pi$ interactions ${ }^{41},{ }^{42}$ in the case of the [ClC15 complex. These energetic repulsions might induce the bound receptor to adopt a conformation different from the cone. The increase in repulsive chloride- $\pi$ interactions derives from the more electron rich nature of the meso-phenyl ring equipped with the gold(I)•PTA ethynyl substituent that is present in $\mathbf{1}$. For the same token, the alkynyl m-system covalently bound to the $\mathrm{Au}^{\mathrm{l}}$ atom largely increases its electron density and may energetically favor the location of the tetraalkylammnoum cation close to it instead of opposed to the bound chloride. This arrangement of the anion and the cation will result in the formation ion-paired complex with close-contact binding geometry having an energy in par with the alternative receptor-separated biding mode even when the bound receptor adopts the cone conformation. For ionpaired complexes in which the bound receptor is not in cone conformation, the close-contact binding geometry should be likely preferred.

In order to assign relative energies and structures to the different binding modes hypothesized for the [Clс15 complex we performed DFT calculation at the bp86 ${ }^{34,35}$-D3 ${ }^{36}$ def2-SVP level of theory and a continuum solvent model using GAUSSIAN 09. ${ }^{37}$ Figure 6 depicts the energy-minimized structures of the $[\mathrm{Cl} \subset 1]$ complexes in which the receptor adopts cone and half-cone conformations. For a fairer energetically comparison, we introduced an implicit molecule of acetone in the structures. This molecule satisfies the hydrogen-bonding needs of the dangling $\mathrm{NH}$ pyrrole on the half-cone bound receptor conformation. The calculations assign an energetic advantage of $2.2 \mathrm{kcal} \mathrm{mol}^{-1}$ to the $[\mathrm{Cl} \subset 1]$ complex with the receptor in cone conformation (Figure 6a).
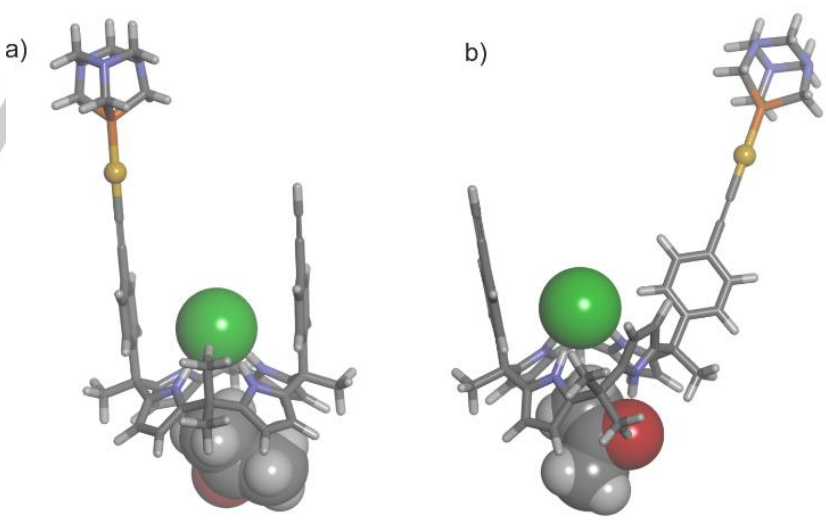

Figure 6. Energy minimized structures bp86-D3 def2-SVP of [Clс15: a) receptor in cone conformation; b) receptor in half-cone conformation. The receptor is shown in ball and stick representation. The chloride and the implicit acetone as CPK models. The gold atom is displayed as scaled ball and stick representation. The calculation assigns an energy advantage of $2.2 \mathrm{Kcal} \mathrm{mol}^{-1}$ to the complex with the receptor in cone conformation.

We postulate that the two sets of proton signals observed for bound 1 in the ${ }^{1} \mathrm{H}$ NMR titrations performed in $\mathrm{DCM}-d_{2}$ and acetone- $d_{6}$ correspond to the two binding geometries of the [Cl $\subset 1]$ complex. ${ }^{43,44}$ The one featuring receptor 1 in cone 
conformation is energetically favored and present in solution largely. We did not compute the structures for the receptor separated or close contact ion-paired complexes of $\mathrm{Cl} \subset \mathbf{1} \cdot \mathrm{TBA} / \mathrm{MTOA}$ because experimentally the cation exchange between the free and bound state is fast on the chemical shift timescale and also a putative chemical exchange between the two sites of the complex should also take place in the same dynamic regime. Consequently, cation exchange processes cannot be considered as responsible for the observation of two separate proton signals of the bound receptor.

\section{Isothermal Titration Calorimetry Experiments in acetone.}

The assessment of accurate values for the binding constant of the anionic complexes formed in acetone was not possible using UV-vis titrations. The absorbance of the solvent is in the range of the absorbance of receptors $\mathbf{1}$ and $\mathbf{2}$. Instead, we performed isothermal titration calorimetry (ITC) experiments (direct and reverse titrations) to characterize thermodynamically the binding processes of both tetraalkylammonium chloride salts, TBACl and $\mathrm{MTOACl}$, with the two receptors $\mathbf{1}$ and $\mathbf{2}$.

In all cases, the resulting exothermic binding isotherms showed a single sigmoidal behavior with the inflexion point centered at a $1: 1$, receptor:salt, ratio. Consequently, we fit all isotherms using a simple $1: 1$ binding model and the thermodynamic parameters returned from the fit $\left(\Delta H\right.$ and $\left.K_{a}\right)$ are referred as apparent values owing to the simplification of the used model, which does not take into account the ion-pairing processes that might occur in the solvent. In other words, we consider that at the concentrations used for the titration, both the salt and the complex are almost fully dissociated. Table 2 summarizes the thermodynamic parameters determined form the ITC experiments.

Table 2. Apparent binding constants $\left(K_{\mathrm{a}}, \mathrm{M}^{-1}\right)$, enthalpies $(\Delta H$, Kcal mol-1) and free energies $\left(\triangle G, \mathrm{Kcal} \mathrm{mol}^{-1}\right)$ of the binding equilibria of 1 and 2 with TAACl salts $\left(\mathrm{TAA}=\mathrm{TBA}^{+}\right.$or $\left.\mathrm{MTOA}^{+}\right)$in acetone at $295 \mathrm{~K}$ using direct ITC titrations. ${ }^{45}$

\begin{tabular}{lllll}
\hline Receptor & \multicolumn{2}{c}{2} \\
\hline Salt & TBACl & MTOACl & TBACl & MTOACl \\
\hline$K_{\mathrm{a} \times 10^{-4}}$ & $1.0 \pm 0.1^{\mathrm{a}}$ & $2.4 \pm 0.2^{\mathrm{a}}$ & $4.8 \pm 0.4^{\mathrm{b}}$ & $7.1 \pm 0.9^{\mathrm{b}}$ \\
$\Delta H$ & $-3.6 \pm 0.2^{\mathrm{a}}$ & $-2.1 \pm 0.4^{\mathrm{a}}$ & $-3.0 \pm 0.1^{\mathrm{b}}$ & $-3.4 \pm 0.1^{\mathrm{b}}$ \\
$\Delta G$ & $-5.3 \pm 0.1$ & $-6.0 \pm 0.1$ & $-6.3 \pm 0.1$ & $-6.5 \pm 0.1$ \\
\hline
\end{tabular}

a $K_{\mathrm{a}}$ and $\Delta H$ are the average values from two independent direct titrations (salt over receptor). Errors are reported as standard deviation. ${ }^{\mathrm{b}} K_{\mathrm{a}}$ and $\Delta H$ are the average values from one direct titration (salt over receptor) and one reverse titration (receptor over salt). Errors are reported as standard deviation of the two measurements.

We can draw several conclusions from the listed data. Firstly, for a given receptor the determined value of the binding constant for its anionic chloride complex should be identical, independently of the salt used as chloride precursor. This would be the expected result if anionic complexes and salts were completely dissociated. However, the obtained results show differences in the binding constant determined for the two salts with a single receptor. For example, the value of $K_{\mathrm{a}}[\mathrm{Cl} \subset 1]$ is slightly larger (double) when MTOACl is used as chloride precursor instead of TBACI. This finding is also observed with receptor 2. Most likely, these results derive from not fully dissociation of ion-pairs in acetone solution. Nevertheless, we consider that in acetone solution the effect of the cation (doubling the $K_{\mathrm{a}}$ values) is markedly reduced compared to DCM solution (two orders of magnitude difference in $K_{a}$ values). Secondly, we have now accurate values for the apparent binding constants of the two receptors with chloride, which although not being identical, they can be used to calculate the effect exerted by the putative chloride- $\pi$ interaction operative in the complexes with receptor 1 . Thus by subtracting the free energies of binding of the two complexes produced by the two salt precursors, we derived a value between $0.8-0.5 \mathrm{kcal} \mathrm{mol}^{-1}$ for the repulsive interaction. This estimate agrees nicely with the calculated one using DFT calculations $\left(0.8 \mathrm{kcal} \mathrm{mol}^{-1}\right)$ on model systems (vide supra). Finally, the binding of chloride in both receptors is both enthalpy and entropy driven. The entropic term is an important component to binding. This observation indicates the importance of the solvation and desolvation processes that take place in polar organic solvents i.e. acetone for the binding of chloride through hydrogen-bonding interactions in deep and polar aromatic clefts.

\section{Conclusions}

In summary, we report the synthesis of an unprecedented organometallic "two wall" $\alpha, \alpha$-calix[4]pyrrole 1 featuring a gold(I) phosphine covalently attached to one of its two para-ethynyl groups in the meso-aryl substituents. In DCM solution, the parent ligand $\mathbf{2}$ and its mono-gold(I) derivative $\mathbf{1}$ act as heteroditopic receptors in the binding of tetraalkylammonium chloride salts producing 1:1 ion-paired complexes. The two receptors show high selectivity and affinity for the binding of methyltrioctyl ammonium chloride (MTOACl) compared to tetrabutyl ammonium chloride (TBACl) owing to the better fit of the methyl group of the MTOA cation in the shallow aromatic cavity opposed to the anion binding site. Moreover, we calculated that the $\mathrm{Cl} \subset \mathbf{1} \cdot \mathrm{TBA}$ complex is energetically destabilized with respect to the ClС2.TBA analogue by $\sim 0.6$ $\mathrm{kcal} \mathrm{mol}{ }^{-1}$ because of stronger repulsive chloride- $\pi$ interactions. The experimentally determined value is in agreement with the one derived from DFT calculations using model systems 4 and 5. The increase in the negative ESP value at the center of the phenyl ring displaying the para-gold(I) phosphine ethynyl substituent is responsible for this deleterious effect and possibly for the existence in solution of the ClС1•TBA/MTOA complexes as a mixtures of two conformers. In the chlorinated solvent, the binding constant values of $\mathrm{Cl} \subset \mathbf{1} \cdot \mathrm{MTOA}$ and $\mathrm{Cl} \subset 2 \cdot \mathrm{MTOA}$ are too large $\left(>10^{4} \mathrm{M}^{-1}\right)$ to be measured accurately using ${ }^{1} \mathrm{H}$ NMR spectroscopy. At $\mu \mathrm{M}$ concentrations, UV-vis titrations in DCM solution revealed the co-existence of the anionic chloride

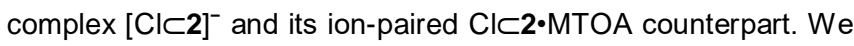
assessed their stability constant using an elaborated binding model. Unfortunately, the results of the UV-vis titrations of $\mathbf{1}$ in DCM were hampered by spectroscopic changes resulting from a 
non-specific interaction between the chloride and the gold(I) aryl-ethynyl residue.

In acetone solution, compounds $\mathbf{1}$ and $\mathbf{2}$ mainly function as homotopic receptors for chloride. The stability constants of the anionic chloride complexes, $[\mathrm{Cl} \subset 1]^{-}$and $[\mathrm{Cl} \subset 2]^{-}$are estimated to be larger than $10^{4} \mathrm{M}^{-1}$ by ${ }^{1} \mathrm{H}$ NMR experiments. The [Clc1] complex is also present as a mixture of two conformers in solution with an slight increase on the amount of the minor component in comparison to DCM. Using ITC experiments, we determined accurate but apparent binding constant values for the two anionic complexes and demonstrated that the cation effect of the salts is markedly reduced in this solvent. We also determined that in acetone the difference in energy between $[\mathrm{Cl} \subset 1]^{-}$and $[\mathrm{Cl} \subset 2]^{-}$is in the range of $0.8-0.5 \mathrm{kcal} \mathrm{mol}^{-1}$ in favor of the later.

\section{Experimental Section}

\section{Synthesis of [Au\{10a,20a-bis(4-} [ethynylphenyl])calix[4]pyrrole\}-(PTA)] (1). A solution of [AuCl(PTA)] (32 mg, $0.08 \mathrm{mmol})$ in $\mathrm{CH}_{2} \mathrm{Cl}_{2}(5 \mathrm{~mL})$ was added to a solution of $\mathrm{KOH}(5 \mathrm{mg}, 0.089 \mathrm{mmol})$ and 10a,20a-bis(4[ethynylphenyl])calix[4]pyrrole (50 $\mathrm{mg}, 0.083 \mathrm{mmol}$ ) in a mixture of $\mathrm{MeOH}(10 \mathrm{~mL})$ and $\mathrm{DCM}(4 \mathrm{~mL})$. After 2 hours of stirring at room temperature, the resulting pale yellow solution was concentrated to ca. $10 \mathrm{~mL}$, and $\mathrm{n}$-hexane $(10 \mathrm{~mL})$ was added to precipitate a pale yellow solid. The filtered solid was recrystallized in $\mathrm{CH}_{2} \mathrm{Cl}_{2} / \mathrm{Hexane}$ solution and isolated by filtration. Yield: $60 \%(45 \mathrm{mg}) .{ }^{1} \mathrm{H}$ NMR $\left(400 \mathrm{MHz},\left(\mathrm{CD}_{3}\right)_{2} \mathrm{CO}\right)$ : 8.77 (br, 2H, N-H), $8.71(\mathrm{br}, 2 \mathrm{H}, \mathrm{N}-\mathrm{H}), 7.33(\mathrm{~d}, 2 \mathrm{H}, J=8.4 \mathrm{~Hz}$ ), $7.12(\mathrm{~d}, 2 \mathrm{H}, J=8.4 \mathrm{~Hz}), 6.92(\mathrm{~d}, 2 \mathrm{H}, J=8.4 \mathrm{~Hz}), 6.77(\mathrm{~d}, 2 \mathrm{H}, J$ $=8.4 \mathrm{~Hz}), 5.78(\mathrm{~m}, 4 \mathrm{H}), 5.60(\mathrm{~s}, 2 \mathrm{H}), 5.56(\mathrm{~s}, 2 \mathrm{H}), 4.65-4.48(\mathrm{~d}$, $\left.3 \mathrm{H}, J=12.8 \mathrm{~Hz}, \mathrm{~N}-\mathrm{CH}_{2}-\mathrm{N}\right), 4.50-4.45(\mathrm{~d}, 3 \mathrm{H}, J=12.8 \mathrm{~Hz}, \mathrm{~N}-$ $\left.\mathrm{CH}_{2}-\mathrm{N}\right), 4.36\left(\mathrm{~s}, 6 \mathrm{H}, \mathrm{P}-\mathrm{CH}_{2}-\mathrm{N}\right), 3.58(\mathrm{~s}, 1 \mathrm{H}, \mathrm{C} \equiv \mathrm{C}-\mathrm{H}), 1.87(\mathrm{~s}$, $\left.3 \mathrm{H}, \mathrm{CH}_{3}\right), 1.83\left(\mathrm{~s}, 3 \mathrm{H}, \mathrm{CH}_{3}\right), 1.65\left(\mathrm{~s}, 6 \mathrm{H}, \mathrm{CH}_{3}\right), 1.48\left(\mathrm{~s}, 6 \mathrm{H}, \mathrm{CH}_{3}\right)$. ${ }^{31} \mathrm{P}\left\{{ }^{1} \mathrm{H}\right\}$ NMR (162 MHz, $\left.\left(\mathrm{CD}_{3}\right)_{2} \mathrm{CO}\right):-47.0 \mathrm{ppm}$. ESI-MS (+) m/z $\left([\mathrm{M}+\mathrm{H}]^{+}\right.$for $\mathrm{C}_{48} \mathrm{H}_{51} \mathrm{AuN}_{7} \mathrm{P}: 954.40$, found 954.40. IR $\left(\mathrm{KBr}, \mathrm{cm}^{-1}\right)$ : $3413 \vee(\mathrm{N}-\mathrm{H}), 3105 \mathrm{v}(\mathrm{C}=\mathrm{C}-\mathrm{H}), 2092 \mathrm{v}(\mathrm{C} \equiv \mathrm{C}), 1637 \mathrm{v}(\mathrm{C}=\mathrm{O}), 1590$ $\mathrm{v}(\mathrm{C}=\mathrm{N})$.

Teorethical calculations. The energy-minimized structures shown in the manuscript were obtained using GAUSSIAN 09. The structures were optimized using DFT-dispersion method BP86-D3-def2-SVP level of theory and a continuum solvent model.

For full experimental details please check the Supporting Information document.

\section{Acknowledgements}

We thank Gobierno de España MINECO (projects CTQ201784319-P and CTQ2016-76120-P), FEDER funds (Projects CTQ2017-84319-P and CTQ2016-76120-P), the CERCA Programme/Generalitat de Catalunya, and AGAUR (2017 SGR
1123) for financial support. Q. S. thanks the Chinese Research Council for a predoctoral fellowship (2017-06870013). We also thank Eduardo C. Escudero-Adán for X-ray crystallography data.

Keywords: Gold(I) phosphine $\cdot$ Calix[4]pyrrole $\cdot$ Supramolecular chemistry $\cdot$ Heteroditopic receptor $•$ Anion- $\pi$ interactions

1 P. A. Gale, J. L. Sessler, V. Kral and V. Lynch, J. Am. Chem. Soc. 1996, 118, 5140-5141.

2 P. A. Gale, J. L. Sessler and V. Kral, Chem. Commun. 1998, 1-8.

3 Y.-D. Wu, D.-F. Wang and J. L. Sessler, J. Org. Chem. 2001, 66, 3739-3746.

4 L. Adriaenssens, C. Estarellas, A. Vargas Jentzsch, M. Martinez Belmonte, S. Matile and P. Ballester, J. Am. Chem. Soc. 2013, 135, 8324-8330.

5 L. Adriaenssens, G. Gil-Ramirez, A. Frontera, D. Quinonero, E. C. Escudero-Adan and P. Ballester, J. Am. Chem. Soc. 2014, 136, 32083218.

6 Y. Han, G.-L. Wang, J.-J. Sun, J. Sun and C.-G. Yan, Tetrahedron 2013, 69, 10604-10609.

7 J. S. Park, K. Y. Yoon, D. S. Kim, V. M. Lynch, C. W. Bielawski, K. P. Johnston and J. L. Sessler, Proc. Natl. Acad. Sci. U. S. A. 2011, 108, 20913-20917.

8 G. Bruno, G. Cafeo, F. H. Kohnke and F. Nicolo, Tetrahedron 2007, 63, 10003-10010

9 J. R. Romero, G. Aragay and P. Ballester, Chem. Sci. 2017, 8, 491-498.

10 S. K. Kim and J. L. Sessler, Acc. Chem. Res. 2014, 47, 2525-2536.

11 I. W. Park, J. Yoo, S. Adhikari, J. S. Park, J. L. Sessler and C. H. Lee, Chem-Eur J 2012, 18, 15073-15078.

12 D. E. Gross, F. P. Schmidtchen, W. Antonius, P. A. Gale, V. M. Lynch and J. L. Sessler, Chem. Eur. J. 2008, 14, 7822-7827.

13 J. L. Sessler, D. E. Gross, W.-S. Cho, V. M. Lynch, F. P. Schmidtchen, G. W. Bates, M. E. Light and P. A. Gale, J. Am. Chem. Soc. 2006, 128, 12281-12288.

14 R. Custelcean, L. H. Delmau, B. A. Moyer, J. L. Sessler, W.-S. Cho, D. Gross, G. W. Bates, S. J. Brooks, M. E. Light and P. A. Gale, Angew. Chem., Int. Ed. 2005, 44, 2537-2542.

15 S. L. Cockroft, Chem 2017, 3, 383-384.

16 R. B. P. Elmes and K. A. Jolliffe, Chem. Commun. 2015, 51, 4951-4968.

17 M. Ferrer, L. Giménez, A. Gutiérrez, J. C. Lima, M. Martínez, L. Rodríguez, A. Martín, R. Puttreddy and K. Rissanen, Dalton Trans. 2017, 46, 13920-13934

18 F. K.-W. Hau, K.-L. Cheung, N. Zhu and V. W.-W. Yam, Organic Chemistry Frontiers 2019, 6, 1205-1213.

19 V. W.-W. Yam, K.-L. Cheung, L.-H. Yuan, K. M.-C. Wong and K.-K. Cheung, Chem. Commun. 2000, 1513-1514.

20 X. He, W. H. Lam, N. Zhu and V. W.-W. Yam, Chem. Eur. J. 2009, 15, 8842-8851.

21 J. Carlos Lima and L. Rodríguez, Chem. Soc. Rev. 2011, 40, 5442-5456.

22 S. Wan and W. Lu, Angew. Chem., Int. Ed. 2017, 56, 1784-1788.

23 C. J. Borman, R. Custelcean, B. P. Hay, N. L. Bill, J. L. Sessler and B. A. Moyer, Chem. Commun. 2011, 47, 7611-7613.

24 V. Valderrey, E. C. Escudero-Adán and P. Ballester, Angew. Chem., Int. Ed. 2013, 52, 6898-6902.

25 V. Valderrey, E. C. Escudero-Adán and P. Ballester, J. Am. Chem. Soc. 2012, 134, 10733-10736.

26 E. Vergara, S. Miranda, F. Mohr, E. Cerrada, E. R. T. Tiekink, P. Romero, A. Mendía and M. Laguna, Eur. J. Inorg. Chem. 2007, 2007, 2926-2933.

27 R. Gavara, J. C. Lima and L. Rodríguez, Photochem. Photobiol. Sci. 2016, 15, 635-643.

28 L. Rodríguez, M. Ferrer, R. Crehuet, J. Anglada and J. C. Lima, Inorg. Chem. 2012, 51, 7636-7641. 
29 E. Aguiló, A. J. Moro, M. Outis, J. Pina, D. Sarmento, J. S. Seixas de Melo, L. Rodríguez and J. C. Lima, Inorg. Chem. 2018, 57, 13423-13430.

30 S. Wan and W. Lu, Angew. Chem., Int. Ed. 2017, 56, 1784-1788.

31 Y. Liu, A. Sengupta, K. Raghavachari and A. H. Flood, Chem 2017, 3, 411427.

32 Protonics Software http://www.hyperquad.co.uk/HypSpec.htm

33 R. M. Fuoss, J. Am. Chem. Soc. 1958, 80, 5059-5061.

34 A. D. Becke, Phys. Rev. A 1988, 38, 3098-3100

35 J. P. Perdew, Phys Rev B 1986, 33, 8822-8824.

36 S. Grimme, J. Antony, S. Ehrlich and H. Krieg, J. Chem. Phys. 2010, 132 154104

37 G. W. T. M. J. Frisch, H. B. Schlegel, G. E. Scuseria, M. A. Robb, J. R. Cheeseman, G. Scalmani, V. Barone, G. A. Petersson, H. Nakatsuji, X. Li, M. Caricato, A. Marenich, J. Bloino, B. G. Janesko, R. Gomperts, B. Mennucci, H. P. Hratchian, J. V. Ortiz, A. F. Izmaylov, J. L. Sonnenberg, D. Williams-Young, F. Ding, F. Lipparini, F. Egidi, J. Goings, B. Peng, A Petrone, T. Henderson, D. Ranasinghe, V. G. Zakrzewski, J. Gao, N. Rega, G. Zheng, W. Liang, M. Hada, M. Ehara, K. Toyota, R. Fukuda, J. Hasegawa, M. Ishida, T. Nakajima, Y. Honda, O. Kitao, H. Nakai, T. Vreven, K. Throssell, J. A. Montgomery, Jr., J. E. Peralta, F. Ogliaro, M. Bearpark, J. J. Heyd, E. Brothers, K. N. Kudin, V. N. Staroverov, T. Keith, R. Kobayashi, J. Normand, K. Raghavachari, A. Rendell, J. C. Burant, S. S. lyengar, J. Tomasi, M. Cossi, J. M. Millam, M. Klene, C. Adamo, R. Cammi, J. W. Ochterski, R. L. Martin, K. Morokuma, O. Farkas, J. B. Foresman, and D. J. Fox, Gaussian, Inc. in Gaussian 09, Revision A 02,, Vol. Wallingford CT, 2016.

$38{ }^{1} \mathrm{H}$ NMR titrations of model compound 6 with TBACl and MTOACl in DCM or acetone do not show noticeable changes in the acquired ${ }^{1} \mathrm{H}$ NMR spectra of 6 before and after the addition of the salts. These findings do not support the existence of strong $\mathrm{Au}-\mathrm{Cl}$ interactions.

39 CCDC 1965694-1965695 contain the supplementary crystallographic data for this paper. These data are provided free of charge by the Cambridge Crystallographic Data Centre.

40 The ${ }^{1} \mathrm{H}$ NMR titrations of the parent ligand 2 in acetone solution with the two salts provided identical results (see SI for details). We concluded that $\mathbf{2}$ acts mainly as homotopic receptor for ion pair binding in acetone and that the stability constant of the anionic chloride complex $[\mathrm{Cl \subset 2}]^{-}$is larger than $10^{4} \mathrm{M}^{-1}$.

41 A. Frontera, P. Gamez, M. Mascal, T. J. Mooibroek and J. Reedijk, Angew. Chem., Int. Ed. 2011, 50, 9564-9583.

42 A. Frontera and P. Ballester in CHAPTER 3 Anion-m Interactions: Theoretical Studies, Supramolecular Chemistry and Catalysis, Vol. The Royal Society of Chemistry, 2017, pp. 39-97.

$43{ }^{1} \mathrm{H}$ NMR titration experiments of 1 with tetraethylammonium chloride (TEACl) in acetone also supports the presence of two conformers for chloride complexes in solution (see Supporting information).

44 The ${ }^{1} \mathrm{H}$ NMR spectrum acquired after the solid-liquid extraction of tetramethylammonium chloride by 1 dissolved in acetone was similar to the one obtained after the addition of $1-2$ equiv. of MTOACl. The ${ }^{1} \mathrm{H}$ NMR spectrum displayed two different sets of proton signals. This observation indicated the presence of the anionic complex in solution as a mixture of two conformers.

45 We also performed ITC experiments of receptors 1 and 2 with tetraethylammonium chloride (TEACI) in acetone. In both cases, the binding constant values for are between those of MTOACl and TBACI (see Supporting Information). 


\section{Entry for the Table of Contents}

\section{FULL PAPER}

The synthesis and binding studies of an unprecedented organometallic "two wall" calix[4]pyrrole bearing one gold(I) phosphine residue at the upper rim is reported. The increase in the negative value of the ESP at the center of the substituted aromatic wall produces stronger repulsive chloride$\pi$ interactions in the resulting complexes compared to the parent ligand.

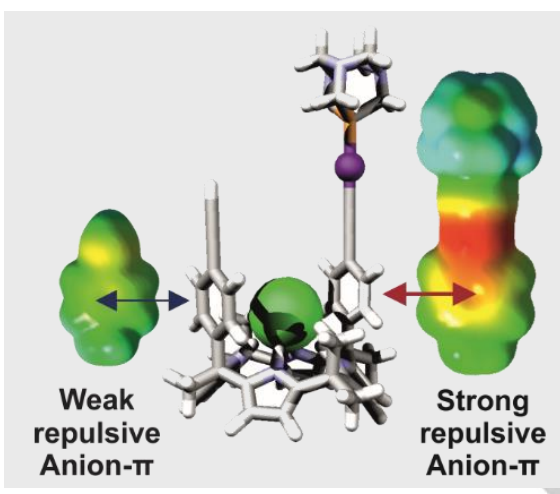

Qingqing Sun, Gemma Aragay, Andrea Pinto, Elisabet Aguiló, Laura Rodríguez* and Pablo Ballester*

Page No. - Page No.

Influence of the Attachment of a Gold(I) Phosphine Moiety at the Upper Rim of a Calix[4]pyrrole on the Binding of Tetraalkylammonium Chloride Salts

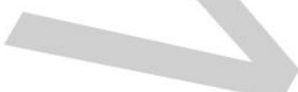

P. A. Gale, J. L. Sessler, V. Kral and V. Lynch, J. Am. Chem. Soc. 1996, 118, 5140-5141.

P. A. Gale, J. L. Sessler and V. Kral, Chem. Commun. 1998, 1-8.

L. Adriaenssens, G. Gil-Ramirez, A. Frontera, D. Quinonero, E. C. Escudero-Adan and P. Ballester, J. Am. Chem. Soc. 2014, 136, 3208-3218.

Y. Han, G.-L. Wang, J.-J. Sun, J. Sun and C.-G. Yan, Tetrahedron 2013, 69, 10604-10609.

L. Adriaenssens, C. Estarellas, A. Vargas Jentzsch, M. Martinez Belmonte, S. Matile and P. Ballester, J. Am. Chem. Soc. 2013, 135, 8324-8330.

J. S. Park, K. Y. Yoon, D. S. Kim, V. M. Lynch, C. W. Bielawski, K. P. Johnston and J. L. Sessler,

Proc. Natl. Acad. Sci. U. S. A. 2011, 108, 20913-20917.

G. Bruno, G. Cafeo, F. H. Kohnke and F. Nicolo, Tetrahedron 2007, 63, 10003-10010.

J. R. Romero, G. Aragay and P. Ballester, Chem. Sci. 2017, 8, 491-498.

S. K. Kim and J. L. Sessler, Acc. Chem. Res. 2014, 47, 2525-2536.

I. W. Park, J. Yoo, S. Adhikari, J. S. Park, J. L. Sessler and C. H. Lee, Chem-Eur J 2012, 18, 1507315078.

D. E. Gross, F. P. Schmidtchen, W. Antonius, P. A. Gale, V. M. Lynch and J. L. Sessler, Chem. Eur. J. 2008, 14, 7822-7827.

J. L. Sessler, D. E. Gross, W.-S. Cho, V. M. Lynch, F. P. Schmidtchen, G. W. Bates, M. E. Light and P. A. Gale, J. Am. Chem. Soc. 2006, 128, 12281-12288.

R. Custelcean, L. H. Delmau, B. A. Moyer, J. L. Sessler, W.-S. Cho, D. Gross, G. W. Bates, S. J. Brooks, M. E. Light and P. A. Gale, Angew. Chem., Int. Ed. 2005, 44, 2537-2542.

V. Valderrey, E. C. Escudero-Adán and P. Ballester, Angew. Chem., Int. Ed. 2013, 52, 6898-6902.

V. Valderrey, E. C. Escudero-Adán and P. Ballester, J. Am. Chem. Soc. 2012, 134, 10733-10736.

Y. Liu, A. Sengupta, K. Raghavachari and A. H. Flood, Chem 2017, 3, 411-427.

R. M. Fuoss, J. Am. Chem. Soc. 1958, 80, 5059-5061.

A. D. Becke, Phys. Rev. A 1988, 38, 3098-3100.

J. P. Perdew, Phys Rev B 1986, 33, 8822-8824.

S. Grimme, J. Antony, S. Ehrlich and H. Krieg, J. Chem. Phys. 2010, 132, 154104.

G. W. T. M. J. Frisch, H. B. Schlegel, G. E. Scuseria, M. A. Robb, J. R. Cheeseman, G. Scalmani, V. Barone, G. A. Petersson, H. Nakatsuji, X. Li, M. Caricato, A. Marenich, J. Bloino, B. G. Janesko, R. Gomperts, B. Mennucci, H. P. Hratchian, J. V. Ortiz, A. F. Izmaylov, J. L. Sonnenberg, D. WilliamsYoung, F. Ding, F. Lipparini, F. Egidi, J. Goings, B. Peng, A. Petrone, T. Henderson, D. Ranasinghe, V. G. Zakrzewski, J. Gao, N. Rega, G. Zheng, W. Liang, M. Hada, M. Ehara, K. Toyota, R. Fukuda, J. 
Hasegawa, M. Ishida, T. Nakajima, Y. Honda, O. Kitao, H. Nakai, T. Vreven, K. Throssell, J. A. Montgomery, Jr., J. E. Peralta, F. Ogliaro, M. Bearpark, J. J. Heyd, E. Brothers, K. N. Kudin, V. N. Staroverov, T. Keith, R. Kobayashi, J. Normand, K. Raghavachari, A. Rendell, J. C. Burant, S. S. Iyengar, J. Tomasi, M. Cossi, J. M. Millam, M. Klene, C. Adamo, R. Cammi, J. W. Ochterski, R. L. Martin, K. Morokuma, O. Farkas, J. B. Foresman, and D. J. Fox, Gaussian, Inc. in Gaussian 09, Revision A 02,, Vol. Wallingford CT, 2016. 